versity. The entire income of the Institute is to be devoted to research. Professor Foley retains charge of the physics department of the university, but is relieved of all teaching duties.

Dr. H. D. Senior, head of the department of anatomy of New York University and Bellevue Medical College, is in England engaged in military medical work. Dr. F. W. Thyng is acting professor of anatomy and head of the department in Dr. Senior's absence, and has charge of histology and embryology. Dr. E. R. Hoskins is acting assistant professor and is in charge of gross anatomy and neurology. Dr. J. L. Conel and Dr. Margaret M. Hoskins are instructors in histology and embryology and Dr. C. Hield is instructor in gross anatomy and neurology. The school year began with 190 students in the first-year class, an increase of 13 over last year.

WARREN G. WATERMan has been appointed assistant professor of botany at Northwestern University, having completed his work at the University of Chicago, where he received the degree of doctor of philosophy at the August convocation.

Professor D'Arcy Wentworth Thompson, professor of natural history, University College, Dundee, has been appointed to the chair of natural history at St. Andrews, vacant through the retirement of Professor W. C. McIntosh.

\section{DISCUSSION AND CORRESPONDENCE BOTANY AND COMMON NAMES OF PLANTS}

To the Editor of Science: Those who favor using the common names of plants, instead of the technical names, probably do not realize the confusion that would result in most instances, where exactness is necessary or desirable, if their suggestions were followed. Imagine the pharmacist relying solely upon the common names in selecting such drugs as mandrake, bitter-sweet, coltsfoot and sarsaparilla. Some of his patrons would surely be poisoned and others would die for want of the proper remedy. Scientific names were given to plants for the express purpose of facilitating exact reference to them and it is a mistaken kindness to teach children and others the common names under the impression that the technical terms are too difficult. Any child who can be taught to say rhinoceros, chrysanthemum or rhododendron can be taught the scientific names of plants and thereby advanced on the road to knowledge, instead of being plunged into a morass of inexact and untrustworthy common names, however poetic. As a matter of fact there is as much poetry and folk-lore in the scientific names as in the common ones. Consider Campanula, Phlox, Asplenium and Helianthemum. Are these less euphonious or poetic than such "common" names as Judge Daly's sunflower, Stewardson Brown's Indian turnip, or Brainerd's cat's foot? There is undoubtedly much literary value in the common names of plants, but the same can not be claimed for the "English" or vernacular names with which we have been deluged of late. A common name is a name that is in common use for the plant in some part of the world and therefore entitled to consideration, but an "English" name is too often merely a poor translation of the scientific name and therefore better left in the original. Common names or, if you please, vernacular names, are still being coined-Christmas fern, foam flower, boulder fern, Darwin tulip, and obedient plant are good illustrations-but who expects such "English" names as repand-leaved erysimum, Hooker's musinon, Gregg's haploesthes, and tall flat-topped white aster to ever become common? In the opinion of many good observers the declining popularity of botany as a high-school study is due in large measure to the efforts of those well-intentioned but misguided popularizers of plant study who either by assertion or implication give to the scientific study of plants a reputation for difficulty which it does not deserve.

It is well to reflect, therefore, that common names can not be made by fiat. If a plant has a common name, we may well use it in the region where the name is common and therefore understood, but to imagine that there is any special sanctity in the common names as such and to insist upon their use on all occasions is as absurd as for the scientist to use technical 
terms in speaking of familiar species. In all cases where exactness is necessary, even wellknown common names will not serve, for often a single plant will have several names or a single common name may be applied to several plants. In spite of the conspicuous differences that still exist between the adherents of the "American Code" and those who advocate the "Vienna Rules," the scientific names are still the safest to go by and all botanists would do well to insist upon their use. The sooner the general public discovers that even technical botany is still "the amiable science" the better it will be for all concerned.

\section{JOLIET, ILL.}

\section{Willard N. Clute}

\section{LACEPÈDE OR LACEPEDE}

IN going over "The Genera of Fishes" recently published by Dr. David Starr Jordan, assisted by Barton Warren Evermann, I discover that these authors accept and adopt the view expressed by Sherborne in his "Index Animalium," p. lvii, where, under the head of "Additions and Corrections," Sherborne says:

A letter dated 1831 is signed "b.g.e cte de lacepede." This spelling and accentuation should be adhered to.

The writer is very much inclined to think that both Sherborne and the learned authors of the recent paper on "The Genera of Fishes" err in accepting the accentuation of the name of the great Frenchman found attached to a scrap of paper bearing his name, which was evidently written in haste. "One swallow does not make a spring," and one hurriedly written autograph with the omission of the acute accent over the first " $\mathrm{e}$ " in the word does not prove that this was the correct way of writing the name. The writer of these lines is called upon every month to attach his signature hundreds of times to vouchers and other documents. He ordinarily puts a period after his initials, $\mathrm{W}$ and $\mathbf{J}$; but only yesterday, having signed some two hundred vouchers, he observed that in the haste of doing so he had in a number of cases omitted the period after his initials. Personal observation shows him that just so it is not an infrequent thing for French gentlemen in hurried writing to omit an accent.

In the judgment of the writer of these lines the existence of one letter in which the French ichthyologist signed himself "lacepède" should not avail against the fact that in all his published writings the other method of accentuation prevails, that all biographies, encyclopædias, and dictionaries, in which the name occurs, give it as "Lacépède." If he were the only person who had borne the name there might be some weight attached to the signature, which Sherborne has turned up; but there were and are others in France who bear the name, and any one who takes the trouble to consult a French dictionary or encyclopædia of biography will find that invariably the name is and has been spelled "Lacépède." The name is so spelled in Buffon, who was the friend and contemporary of Lacépède, and I think it seems "rather late in the day" to change the universally accepted spelling of the name of the well-known naturalist on the strength of the L. S. discovered by Sherborne.

To be consistent, if the acute accent is omitted on the first "e," the capitals should also cease to be employed, not only in the family, but also the Christian names of Lacépède, for in the autograph which Sherborne quotes the name is written throughout without capitals. After carefully weighing the matter the writer is of the opinion that Buffon, the authors of the "Dictionnaire Universelle," and the thousand or more Frenchmen engaged in scientific research, who have for over a century written the name "Lacépède" are more likely to know what is correct than the author of the "Index Mammalium," who, having unearthed this L. S., has on the strength of it proceded in this particular to overthrow the usage of more than a century, and the usage of those who were the friends and acquaintances of Lacépède himself.

Pittisburgh, Pa.,

October 17, 1917

FORBES WINSLOW MEMORIAL HOSPITAL

To THE Editor of ScIEnce: The British Ministry of Pensions has recognized and authorized for trial psychical treatment for 